\title{
Verbal Fluency: An Investigation of Time Variable Among Elderly People
}

\author{
Sevket Ozdemir ${ }^{1}$ (D), Aylin Muge Tuncer ${ }^{2}$ \\ ${ }^{1}$ Department of Special Education, Hacettepe University, Ankara, Turkey. \\ ${ }^{2}$ Department of Speech and Language Therapy, Anadolu University, Eskisehir, Turkey. \\ Correspondence Author: Sevket Ozdemir \\ E-mail: sevketozdemir@hacettepe.edu.tr \\ Received: $27.04 .2020 \quad$ Accepted: 14.03 .2021
}

\begin{abstract}
Objective: Little is known about the impact of time on verbal fluency performance among the elderly population. The aims of this study were to (i) examine the verbal fluency (semantic and action fluency) performance across four quarters of 60 seconds and (ii) explore the relationship between demographic (education and age) and time variables on the performance of elderly individuals.

Methods: A descriptive correlational and comparative study of 58 elderly healthy subjects was carried out (range, 60-81 years). Five semantic categories and action fluency were implemented. Participants were stratified into three education groups (Group 1, 2 and 3 including subjects with 5-8 years, 9-11 and more than 12 years of schooling) and each group involved 20, 21 and 17 participants respectively.

Results: The findings revealed mean numbers of words among quarters decreased in a linear fashion. There was significant difference between the production in the first quarter and others. It was seen that age did not correlate with fluency performance across quarters. Significant production differences were found between education groups across all quarters.

Conclusion: This study demonstrates the fluency scores of elderly healthy subjects with different levels of education along with production across four quarters. It is suggested that future studies include neuropathological conditions for the clinical utility of these measures.

Keywords: semantic fluency, action fluency, time, education, age.
\end{abstract}

\section{INTRODUCTION}

Verbal fluency (VF) tasks comprise an essential part of neuropsychological assessment. They refer to verbal production within a designated time (usually $1 \mathrm{~min}$ ) following certain instructions provided (1). Quick and easy to implement, these measures help clinicians assess a wide range of neurological conditions including Alzheimer's disease, Parkinson's disease, primary progressive aphasia, fronto-temporal dementia and post-stroke aphasia (2-5). These tasks are widely used by speech and language therapists (SLTs) and neuropsychologists to assess word retrieval from the lexicon and semantic memory. The VF performances are evaluated through the correct number of words by excluding those that are repeated or out of the category (6).

Three types of fluency tasks exist in the literature: Semantic, action and phonemic. While the first two tasks involve producing either noun or verb categories, the final task is related to uttering words beginning with the same phoneme (most commonly /f/,/a/,/s/). The use of "animal" category is most common among semantic fluency tasks, while "naming things that people do" without adding any inflectional markers (e.g., sleep and sleeping) is expected in action fluency (7). It is articulated that patients with Alzheimer's disease and semantic dementia hold poorer performance in semantic fluency task as impairment in semantic memory among these conditions is extensively reported (5,8-9). It is also pointed out that action fluency task can be used to assess executive functions among healthy individuals, which is supported by its correlation with other executive function measures (10-11). Action fluency is also reported to hold potential in distinguishing Parkinson's disease with dementia (PDD) from non-demented Parkinson's disease (7), Lewy body dementia and behavioral variant of frontotemporal dementia from Alzheimer's dementia $(3,12)$. Besides its significance in clinical context, the interaction between demographic variables (education, age and gender) and verbal fluency performance has been widely studied among healthy individuals in different languages $(1,13)$.

In addition to these variables, studies including semantic and phonemic fluency tasks investigated the relationship between time and demographic variables among young 
or elderly participants (14-19). These studies divided 60 seconds into two halves $(16,18)$ or four quarters $(15,17)$. The conclusion drawn from the findings of the studies involving elderly participants attached a positive influence of education (14,17-18). They also stated that the production in the first quarter (first $15 \mathrm{~s}$ ) was significantly more than the ones in other quarters $(15,17)$. They proposed that word production at later quarters became effortful and required a robust executive function (involving self-monitoring abilities, processing speed, etc.) and attention control (15-17). Few studies also asserted that following a semantic fluency task using "Animal" category with a 30-second measure, it was possible to differentiate healthy subjects from patients with Mild Cognitive Impairment (19) and stroke patients with aphasia from those without aphasia (20). Regarding aphasia, a recent study by Bose, Wood and Kiran revealed that the words uttered by people with aphasia (PwA) and control participants in the first $15 \mathrm{~s}$ of animal fluency task were more than those in the remaining three quarters, followed by a progressive decrease in production and a final "asymptote" (21). Furthermore, one study investigated the semantic fluency performance of young adults with high-functioning Autism Spectrum Disorders (ASD), and stated that the performance in the first $30 \mathrm{~s}$ of the task was significantly lagging behind that of the control group. The authors concluded that their results could refer to deficits in the initiation processes in ASD (22).

VF measures including semantic, phonemic and action were examined among Turkish-speaking individuals (23-29). The "animal" category was the most common. This was utilized both among healthy people $(23,25-26)$ and those with neurological conditions such as Alzheimer's dementia (AD) (27) and fronto-temporal dementia (28). The other semantic categories included fruits-vegetables, furniture, body parts and clothes $(23,25-26)$. Moreover, the performances of PwA and healthy participants on the household items and kitchen utensils categories were examined as part of the reliability and validity analyses of Aphasia Assessment Tool (ADD) in Turkish (29). It was concluded that education and age had a significant effect on the semantic fluency performances of healthy participants (23). Two studies examined the action fluency (AF) performances of healthy Turkish-speaking adolescents aged between 15 and 17. The findings of these studies showed that the mean number of correct verbs was 16.26 and there was no statistical difference between the AF performances of participants who were 15,16 and 17 years old (25-26).

As mentioned, previous studies have examined the performance of semantic and phonemic fluency tasks in different time phases during one minute. In this regard, this study aimed to (i) examine the performance across four quarters of 60 seconds through action and semantic fluency tasks (ii) explore the relationship between demographic (education and age) and time variables on fluency performance of elderly individuals.

\section{METHODS}

A descriptive correlational and comparative study was carried out. The sample of the study contained 58 elderly neurotypical subjects (28 female, 30 male). The mean age was 65.43 years (range 60-81; SD: 5.51). Participants were stratified into three educational groups: Group 1 (5-8 years of schooling), Group 2 (9-11 years of schooling), Group 3 (more than 12 years of schooling). The groups consisted of 20, 21 and 17 participants respectively. All of the subjects were healthy with no cognitive, neurological or psychiatric complaints and conditions. Mini-Mental State Examination (MMSE) was administered in order to ensure this requirement. All the participants scored more than 24 which was the cut-off score for healthy subjects in MMSE as provided by Güngen et al. for Turkish population (30). It is important to note that the authors included participants with at least 5 years of schooling but did not stratify MMSE scores according to the education profile of the participants in their study. The study received the approval of the Ethical Committee of Anadolu University (Protocol no. 6085). Prior to initiating the tasks, all the participants gave a written consent to take part in the study.

Five semantic fluency categories ("Breakfast Items, Famous People, Food, Beverages and Household (tems") and AF test were administered. The instructions were provided as simple as possible. The subjects were asked to name as many breakfast items, famous people, food, beverages and household items as possible. It was stressed that it could be all types of food and beverages, all items for breakfast and house, and famous people known by a large majority of Turkish population. As for AF, the instructions were given in the format presented by Piatt et al. (7): "I would like you to tell me as many different things as you can think of that people do. I do not want you to use the same word with different endings, like eat, eaten, eating. Also, just give me single words such as eat, or run, rather than a sentence. Can you give me one example of something that people do?" As long as this example was correct, they were asked to initiate the task with this example. The administration of all the tasks was conducted in a silent environment by the first author in one session. The order of the administration was the same for all the participants: Breakfast Items, Famous People, Food, Beverages, Household Items (all belonging to Semantic Fluency) and Action Fluency. The phonemic fluency measure was not included in the study; the categorical production was emphasized. Moreover, the semantic categories including "animals" along with "supermarket, fruits-vegetables" were not investigated in this study, albeit their widespread clinical use. This was due to the fact that the effect of time variable on the categories utilized in this study was investigated.

The scores of all the participants were recorded by either using a VoiceRecorder App for Apple Iphone or an MP3 player (Sony NWZ-B173). They were all later transcribed in Microsoft Excel. The time was set to be 1 minute ( 60 seconds) during fluency assessment. This time limit is frequently used in the literature, even though there are other studies utilizing two minutes 
(120 seconds) for categorical fluency measures (18). Excluding those that were repeated and out of the category, the words produced in four quarters were examined (1-15 seconds, 1630 seconds, 31-45 seconds, 46-60 seconds). The performance between each quarter among all the tasks was examined.

Parametric and non-parametric tests were used in all of the statistical analyses. As for the comparison of performance between quarters, Friedman Test was applied. Regarding the pairwise comparisons, Wilcoxon signed-rank test was employed so that any significant differences between quarters would be explored. Spearman's Rho Correlation Coefficient was calculated in order to analyze the relationship between age and the production across quarters. As descriptive values of mean scores across quarters belonging to all education groups exhibited normal distribution, ANOVA was administered to investigate whether there were production differences between education groups among different quarters. The significance level of .05 was taken into account within all the analyses.

\section{RESULTS}

58 elderly subjects participated in the study. Figure 1 reveals mean number of items produced among four quarters. Table 1 shows the Friedman test results which compared the fluency performance between the quarters. Table $\mathbf{2}$ indicates Wilcoxon test results which included pairwise comparisons between items produced in different quarters. Table $\mathbf{3}$ shows the correlation between age and production among quarters. Finally, Table 4 demonstrates both descriptive values and ANOVA results as performance of education groups within all the quarters was examined.

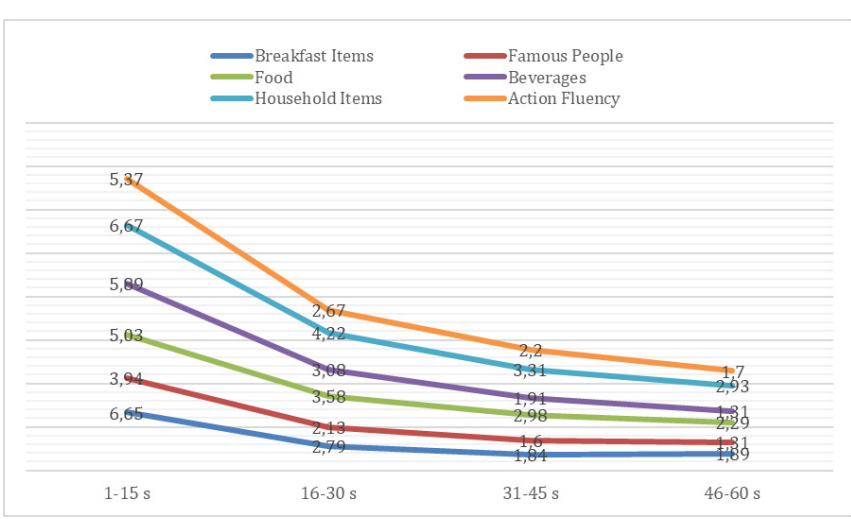

Figure 1: Mean Number of Items Produced Among Different Quarters

It was seen that the mean number of words produced among quarters decreased in a linear way (Figure 1). This was statistically significant for all semantic and action fluency measures following the results of the Friedman test (Breakfast Items: $\chi^{2}(3)=101.015, p<.001$; Famous People: $\chi^{2}(3)=$ 81.226, $p<.001$; Food: $\chi^{2}(3)=72.473, p<.001$; Beverages: $\chi^{2}(3)$ $=129.786, p<.001$; Household Items: $\chi^{2}(3)=96.959, p<.001$; Action Fluency: $\left.\chi^{2}(3)=109.180, p<.001\right)$ (Table 1).
Table 1. Mean Number of Items Produced Among Different Quarters and Friedman Test Results

\begin{tabular}{|c|c|c|c|c|c|}
\hline Categories & $n$ & Mean & SD & $\chi^{2}(\mathrm{df})$ & $p$ \\
\hline \multicolumn{6}{|c|}{ Breakfast Items } \\
\hline $1^{\text {st }}$ Quarter & 58 & 6.65 & 2.35 & $101.015(3)$ & $.000 *$ \\
\hline $2^{\text {nd }}$ Quarter & 58 & 2.79 & 1.76 & & \\
\hline $3^{\text {rd }}$ Quarter & 58 & 1.84 & 1.51 & & \\
\hline $4^{\text {th }}$ Quarter & 58 & 1.89 & 1.54 & & \\
\hline Total & 58 & 13.18 & 4.71 & & \\
\hline \multicolumn{6}{|c|}{ Famous People } \\
\hline $1^{\text {st }}$ Quarter & 58 & 3.94 & 1.65 & $81.226(3)$ & $.000^{*}$ \\
\hline $2^{\text {nd }}$ Quarter & 58 & 2.13 & 1.53 & & \\
\hline $3^{\text {rd }}$ Quarter & 58 & 1.60 & 1.37 & & \\
\hline $4^{\text {th }}$ Quarter & 58 & 1.31 & 1.25 & & \\
\hline Total & 58 & 9.00 & 4.15 & & \\
\hline \multicolumn{6}{|l|}{ Food } \\
\hline $1^{\text {st }}$ Quarter & 58 & 5.03 & 1.58 & $72.473(3)$ & $.000^{*}$ \\
\hline $2^{\text {nd }}$ Quarter & 58 & 3.58 & 1.53 & & \\
\hline $3^{\text {rd }}$ Quarter & 58 & 2.98 & 1.61 & & \\
\hline $4^{\text {th }}$ Quarter & 58 & 2.29 & 1.73 & & \\
\hline Total & 58 & 13.89 & 4.62 & & \\
\hline \multicolumn{6}{|l|}{ Beverages } \\
\hline $1^{\text {st }}$ Quarter & 58 & 5.89 & 2.10 & $129.786(3)$ & $.000^{*}$ \\
\hline $2^{\text {nd }}$ Quarter & 58 & 3.08 & 1.49 & & \\
\hline $3^{\text {rd }}$ Quarter & 58 & 1.91 & 1.58 & & \\
\hline $4^{\text {th }}$ Quarter & 58 & 1.31 & 1.09 & & \\
\hline Total & 58 & 12.20 & 4.16 & & \\
\hline \multicolumn{6}{|l|}{$\begin{array}{l}\text { Household } \\
\text { Items }\end{array}$} \\
\hline $1^{\text {st }}$ Quarter & 58 & 6.67 & 2.21 & $96.959(3)$ & $.000^{*}$ \\
\hline $2^{\text {nd }}$ Quarter & 58 & 4.22 & 1.87 & & \\
\hline $3^{\text {rd }}$ Quarter & 58 & 3.31 & 1.72 & & \\
\hline $4^{\text {th }}$ Quarter & 58 & 2.93 & 1.84 & & \\
\hline Total & 58 & 17.13 & 5.62 & & \\
\hline \multicolumn{6}{|c|}{ Action Fluency } \\
\hline $1^{\text {st }}$ Quarter & 58 & 5.37 & 2.20 & $109.180(3)$ & $.000^{*}$ \\
\hline $2^{\text {nd }}$ Quarter & 58 & 2.67 & 1.60 & & \\
\hline $3^{\text {rd }}$ Quarter & 58 & 2.20 & 1.47 & & \\
\hline $4^{\text {th }}$ Quarter & 58 & 1.70 & 1.52 & & \\
\hline Total & 58 & 11.96 & 5.30 & & \\
\hline
\end{tabular}

Significant difference was found in all the categories between the $1^{\text {st }}$ and $2^{\text {nd }}$ quarters $(Z=-6.288, p<.001$ for Breakfast Items; $Z=-5.862, p<.001$ for Famous People; $Z=-4.681$, $\mathrm{p}<.001$ for Food; $Z=-6.370, \mathrm{p}<.001$ for Beverages; $Z=-$ $5.876, p<.001$ for Household Items; $Z=-6.479, p<.001$ for Action Fluency), the $1^{\text {st }}$ and $3^{\text {rd }}$ quarters $(Z=-6.501, p<.001$ for Breakfast Items; $Z=-6.322, p<.001$ for Famous People; $Z$ $=-5.668, p<.001$ for Food; $Z=-6.355, p<.001$ for Beverages; $Z=-6.308, p<.001$ for Household Items; $Z=-6.392, p<.001$ for Action Fluency), and the $1^{\text {st }}$ and $4^{\text {th }}$ quarters $(Z=-6.530$, $p<.001$ for Breakfast Items; $Z=-6.206, p<.001$ for Famous People; $Z=-6.075, p<.001$ for Food; $Z=-6.586, p<.001$ for Beverages; $Z=-6.111, p<.001$ for Household Items; $Z$ $=-6.532, p<.001$ for Action Fluency) (Table 2). Moreover, significant production differences were seen between the 
$2^{\text {nd }}$ and $3^{\text {rd }}$ quarters $(Z=-3.458, p<.01$ for Breakfast Items; $Z=-2.660, p<.01$ for Famous People; $Z=-2.348, p<.05$ for Food; $Z=-4.073, p<.001$ for Beverages; $Z=-3.534, p<.001$ for Household Items; $Z=-2.255, p<.05$ for Action Fluency), and the $2^{\text {nd }}$ and $4^{\text {th }}$ quarters $(Z=-3.185, p<.01$ for Breakfast Items; $Z=-2.996, p<.01$ for Famous People; $Z=-4.435$, $p<.001$ for Food; $Z=-5.597, p<.001$ for Beverages; $Z=-$ 3.945, $p<.001$ for Household Items; $Z=-3.865, p<.001$ for Action Fluency) (Table 2). These two findings show that the number of words in the first and second quarters were more in number than the others produced in the last two quarters. The production differences between the $3^{\text {rd }}$ and $4^{\text {th }}$ quarters were significant among Food $(Z=-2.885, p<.01)$, Beverages $(Z=-2.557, p<.05)$ and Action Fluency $(Z=-2.487, p<.05)$. However, contrary findings were seen among Breakfast Items $(Z=-.189, p=.850)$, Famous People $(Z=-1.328, p=.184)$ and Household Items $(Z=-1.389, p=.165)$ in this interval. Results also revealed that there was no statistically significant correlation between age and fluency tasks (Table 3).

Table 2. Results of Wilcoxon signed-rank Test

\begin{tabular}{ccccccccccccc} 
Quarters & \multicolumn{2}{c}{ Breakfast Items } & \multicolumn{2}{c}{ Famous People } & \multicolumn{2}{c}{ Food } & \multicolumn{2}{c}{ Beverages } & \multicolumn{2}{c}{ Household Items } & Action Fluency \\
\hline & $\mathrm{p}$ & $\mathrm{Z}$ & $\mathrm{p}$ & $\mathrm{Z}$ & $\mathrm{p}$ & $\mathrm{Z}$ & $\mathrm{p}$ & $\mathrm{Z}$ & $\mathrm{p}$ & $\mathrm{Z}$ & $\mathrm{p}$ & $\mathrm{Z}$ \\
\hline $1 \times 2$ & $.000^{* * *}$ & -6.288 & $.000^{* * *}$ & -5.862 & $.000^{* * *}$ & -4.681 & $.000^{* * *}$ & -6.370 & $.000^{* * *}$ & -5.876 & $.000^{* * *}$ & -6.479 \\
$1 \times 3$ & $.000^{* * *}$ & -6.501 & $.000^{* * *}$ & -6.322 & $.000^{* * *}$ & -5.668 & $.000^{* * *}$ & -6.355 & $.000^{* * *}$ & -6.308 & $.000^{* * *}$ & -6.392 \\
$1 \times 4$ & $.000^{* * *}$ & -6.530 & $.000^{* * *}$ & -6.206 & $.000^{* * *}$ & -6.075 & $.000^{* * *}$ & -6.586 & $.000^{* * *}$ & -6.111 & $.000^{* * *}$ & -6.532 \\
$2 \times 3$ & $.001^{* *}$ & -3.458 & $.008^{* *}$ & -2.660 & $.019^{*}$ & -2.348 & $.000^{* * *}$ & -4.073 & $.000^{* * *}$ & -3.534 & $.024^{*}$ & -2.255 \\
$2 \times 4$ & $.001^{* *}$ & -3.185 & $.003^{* *}$ & -2.996 & $.000^{* * *}$ & -4.435 & $.000^{* * *}$ & -5.597 & $.000^{* * *}$ & -3.945 & $.000^{* * *}$ & -3.865 \\
\hline $3 \times 4$ & .850 & -.189 & .184 & -1.328 & $.004^{* *}$ & -2.885 & $.011^{*}$ & -2.557 & .165 & -1.389 & $.013^{*}$ & -2.487 \\
\hline
\end{tabular}

${ }^{*} p<.05,{ }^{* *} p<.01,{ }^{* * *} p<.001$

Table 3. Results of Spearman's Correlation

\begin{tabular}{llll} 
Variables & Quarters & $\mathbf{r}_{\mathrm{s}}$ & $\mathbf{p}$ \\
\hline Age $\times$ Semantic Fluency & $1^{\text {st }}$ quarter & -0.057 & 0.669 \\
& $2^{\text {nd }}$ quarter & -0.170 & 0.202 \\
& $3^{\text {rd }}$ quarter & -0.079 & 0.556 \\
& $4^{\text {th }}$ quarter & -0.187 & 0.161 \\
\hline Total & -0.125 & 0.348 \\
\hline & $1^{\text {st }}$ quarter & 0.000 & 0.997 \\
\hline $2^{\text {nd }}$ quarter & 0.138 & 0.300 \\
\hline & $3^{\text {rd }}$ quarter & -0.021 & 0.879 \\
& $4^{\text {th }}$ quarter & -0.186 & 0.163 \\
\hline & Total & -0.015 & 0.911 \\
\hline
\end{tabular}

Table 4. Descriptive values (means and standard deviation) and ANOVA results for fluency performance belonging to education groups across quarters, and Post-Hoc results between groups.

\begin{tabular}{|c|c|c|c|c|c|c|c|c|c|c|c|}
\hline \multirow[t]{2}{*}{ Variables } & \multirow[t]{2}{*}{ Quarters } & \multicolumn{2}{|c|}{$\begin{array}{c}\text { Group } 1 \\
\text { (5-8 years of schooling) } \\
n=20\end{array}$} & \multicolumn{2}{|c|}{$\begin{array}{c}\text { Group } 2 \\
\text { (9-11 years of } \\
\text { schooling) } \\
n=21\end{array}$} & \multicolumn{2}{|c|}{$\begin{array}{c}\text { Group } 3 \text { (more } \\
\text { than } 12 \text { years of } \\
\text { schooling) } \\
n=17\end{array}$} & \multirow[t]{2}{*}{ df } & \multirow[t]{2}{*}{$\mathbf{F}$} & \multirow[t]{2}{*}{$p$} & \multirow[t]{2}{*}{ Post-hoc } \\
\hline & & Mean & SD & Mean & SD & Mean & SD & & & & \\
\hline \multirow{5}{*}{$\begin{array}{c}\text { Education } \mathrm{x} \\
\text { Semantic Fluency }\end{array}$} & $1^{\text {st }}$ quarter & 4.79 & 1.55 & 5.56 & 1.13 & 6.74 & 1.46 & 2 & 9.110 & $.000^{* * *}$ & Group 1-3 \\
\hline & $2^{\text {nd }}$ quarter & 2.59 & 1.16 & 3.20 & 1.06 & 3.80 & 0.88 & 2 & 6.083 & $.004^{* *}$ & Group 1-3 \\
\hline & $3^{\text {rd }}$ quarter & 1.74 & 0.88 & 2.29 & 0.78 & 3.07 & 0.90 & 2 & 11.177 & $.000 * * *$ & Group 1-3 \\
\hline & $4^{\text {th }}$ quarter & 1.49 & 0.90 & 1.76 & 0.88 & 2.71 & 0.71 & 2 & 10.472 & $.000 * * *$ & $\begin{array}{c}\text { Group 1-3, } \\
2-3\end{array}$ \\
\hline & Total & 10.61 & 3.78 & 12.81 & 2.85 & 16.32 & 2.93 & 2 & 14.537 & $.000 * * *$ & $\begin{array}{c}\text { Group 1-3, } \\
2-3\end{array}$ \\
\hline \multirow{5}{*}{$\begin{array}{c}\text { Education } x \\
\text { Action Fluency }\end{array}$} & $1^{\text {st }}$ quarter & 4.20 & 1.93 & 5.61 & 2.31 & 6.47 & 1.77 & 2 & 5.932 & $.005^{* *}$ & Group 1-3 \\
\hline & $2^{\text {nd }}$ quarter & 2.00 & 1.89 & 2.52 & 1.24 & 3.64 & 1.16 & 2 & 5.825 & $.005^{* *}$ & Group 1-3 \\
\hline & $3^{\text {rd }}$ quarter & 1.30 & 1.26 & 2.28 & 1.14 & 3.17 & 1.46 & 2 & 9.845 & $.000^{* * *}$ & Group 1-3 \\
\hline & $4^{\text {th }}$ quarter & 1.30 & 1.41 & 1.47 & 1.28 & 2.47 & 1.69 & 2 & 3.352 & $.042^{*}$ & Group 1-3 \\
\hline & Total & 8.80 & 5.28 & 11.90 & 3.78 & 15.76 & 4.60 & 2 & 10.606 & $.000 * * *$ & Group 1-3 \\
\hline
\end{tabular}

${ }^{*} p<.05,{ }^{* *} p<.01,{ }^{* * *} p<.001$ 
It was seen that mean numbers of words decreased between quarters within all education groups. The analysis of variance (ANOVA) results revealed that the decrease in production was statistically significant among all quarters. Scheffe's test results for post-hoc comparisons demonstrated that participants with 5-8 years of schooling (Group 1) produced significantly less number of words than those with more than 12 years of schooling (Group 3) in all the quarters within semantic fluency measure $\left(F(2)=9.110, p<.001\right.$ for $1^{\text {st }}$ quarter; $F(2)=6.083, p<.01$ for $2^{\text {nd }}$ quarter; $F(2)=11.177$, $p<.001$ for $3^{\text {rd }}$ quarter; $F(2)=10.472, p<.001$ for $4^{\text {th }}$ quarter; $F(2)=14.537, p<.001$ for total). These comparisons also showed that participants in Group 2 scored significantly less than those in Group 3 in the last quarter in semantic fluency $(F(2)=10.472, p<.001)$. As for the action fluency, it was observed that participants with more than 12 years of schooling (Group 3) generated a greater number of words than those with 5-8 years of schooling (Group 1) across all quarters $\left(F(2)=5.932, p<.01\right.$ for $1^{\text {st }}$ quarter; $F(2)=5.825$, $p<.01$ for $2^{\text {nd }}$ quarter; $F(2)=9.845, p<.001$ for $3^{\text {rd }}$ quarter; $F(2)$ $=3.352, p<.05$ for $4^{\text {th }}$ quarter; $F(2)=10.606, p<.001$ for total).

\section{DISCUSSION}

The present study revealed production differences among four quarters. It also examined the interaction between demographic and time variables. Regarding the first aim, it was seen that fluency performance of the subjects decreased in a linear way between the quarters. Post-hoc analysis of this decrease demonstrated that mean number of words produced in the first quarter was significantly more than those of other quarters for all semantic categories and action fluency.

Even though different categories were analyzed in other studies, these findings are consistent with previous studies that examined production differences between four quarters $(14-15,17)$. Crowe (1998) found out that the decrease across quarters were linear and the amount of words produced in the first quarter was statistically more than those in other quarters (15). Brucki and Rocha (2004) reported similar finding regarding the latter result (14). This result complies with the findings of these studies. Though Crowe (1998) included subjects between 18 and 35 years of age, he concluded that as time passes searching for additional words and retrieving them become more challenging after the pool of readily frequent words was eventually exhausted (15). Moreover, Venegas and Mansur (2011) indicated that the performance in the first quartile was significantly different than the one in other quarters in that approximately half of the total words in the semantic fluency task ("animal" category) was produced during the initial 15 seconds (17). In a recent study, Demetriou and Holtzer (2017) concluded that healthy older participants produced significantly more number of words in the first $20 \mathrm{~s}$ of semantic fluency measures compared to adults with Mild Cognitive Impairment. They stressed that efficient search processes and monitoring abilities along with fast word retrieval from memory contributed to the performance of healthy older adults (31).

The second aim was to explore whether there is a relationship between demographic variables (education and age) and time on fluency performance. This study revealed no relationship between age and verbal fluency measures (both semantic and action) while the performance in all the quarters was considered. This is consistent with the findings of previous studies $(14,17)$.

Furthermore, it was found that participants with more than 12 years of schooling (Group 3 ) produced a higher number of words among all the quarters both in semantic and action fluency tasks compared to the ones generated by the subjects with 5-8 years of schooling (Group 1). The impact of education on verbal fluency performance was articulated substantially in the neuropsychology literature. Regarding semantic fluency, Venegas and Mansur (2011) asserted that the performance pertaining to the first quarter holds potential to reflect the compactness of semantic memory. While this compactness was referred as "semantic sketch resources", the performance in the following quarters $\left(2^{\text {nd }}\right.$ and $3^{\text {rd }}$ quarters) was reported to be influenced by cognitive operations such as planning and monitoring (17). Brucki and Rocha (2004) provided findings in the similar vein: They found out that higher education levels could be associated with higher production across quarters (14).

Previous studies related to action fluency also reported the influence of education. However, as far as the knowledge of the study's authors, there is no other study that investigated the impact of time variable on the action fluency performance. As there is a strong emphasis on the possibility of using action fluency test as a measure of executive function (1011 ), it might be useful to investigate the performance across intervals in other languages. Moreover, previous studies reported that performance across time in semantic fluency task could be an indicator of predicting the diagnosis of mild cognitive impairment (19) as well as distinguishing aphasic people from non-aphasic population (20). In reference to these studies, the clinical utility of action fluency task could be explored by further analyzing the performance across intervals within neuropsychological evaluations.

Previous fluency studies that include Turkish-speaking healthy individuals have not examined the effect of the time variable on the fluency performances. However, Kırbaç (2015) reported that the mean number of verbs produced by the participants who were between 15 and 17 years of age was 16.26 (25). The current study showed that the mean number of actions uttered by those who were between 60 and 81 years of age was 11.96. This difference might be remarkable. However, these two studies included different age groups. Moreover, Maviş and Toğram (2009) stated that the highest mean number of correct words in household items category was derived from those who were between 23-44 years of age (mean $=14.2)$ and received more than 12 years of education (mean $=14)$. They also reported that the lowest values in the category were obtained from those who 
were above 75 years of age and illiterate individuals (mean for both $=8$ ). The current study showed that the mean number of total correct words in the household items category (mean $=17.13 ; \mathrm{SD}=5.62$ ) was more than those that were presented by Maviş and Toğram (2009) (29).

This study holds some limitations. Initially semantic fluency categories in this study are different from those that are commonly used in the neuropsychology literature. Regarding action fluency, it is recommended that the number of elderly healthy individuals be increased and neuropathological conditions (such as Parkinson's and Alzheimer's disease) be included to establish norms for clinical utility within Turkish context.

\section{CONCLUSION}

This study investigated the effect of time variable on the semantic and action fluency performances of the elderly people who were between 60 and 81 . The production differences within the four time intervals were examined within semantic (breakfast, famous people, food, beverages, household items) and action fluency measures. It is anticipated that this study will contribute to the literature in terms of the production differences between time intervals and the interaction of time and demographic variables such as education and age. Moreover, the action fluency findings reported in this study will provide a reference especially for the studies including patients with Parkinson's disease since action fluency measures hold a particular clinical utility and significance for this population. Regarding the suggestions for future studies, first, various cognitive assessment tools measuring verbal intelligence and executive functions could be utilized. The findings of these tools could be compared with those of the fluency measures. The correlations between these findings could be examined. Second, the participants who are proficient in more than one language could be included to observe whether bilingualism holds any effect on the fluency performance. Third, neuropathological conditions such as Alzheimer's disease, Parkinson's disease, frontotemporal dementia could be included to test the clinical utility of these measures.

Acknowledgements: We thank Hüsniyenur Yazıcı for helping us recruit the participants of the study.

\section{REFERENCES}

[1] Lezak MD, Howieson DB, Bigler ED, Tranel D. Neuropsychological assessment. 5th ed. New York, NY: Oxford University Press; 2012.

[2] Beber BC, da Cruz AN, Chaves ML. A behavioral study of the nature of verb production deficits in Alzheimer's disease. Brain Lang 2015; 149:128-34.

[3] Davis C, Heidler-Gary J, Gottesman R, et al. Action versus animal naming fluency in subcortical dementia, frontal dementias, and Alzheimer's disease. Neurocase 2010; 16(3):259-266.
[4] Faroqi-Shah Y, Milman, L. Comparison of animal, action and phonemic fluency in aphasia. Int J Lang Commun Disord 2018; 53(2):370-84.

[5] Henry JD, Crawford JR, Philips LH. Verbal fluency performance in dementia of the Alzheimer's type: A meta-analysis. Neuropsychol 2004; 42(9):1212-1222.

[6] Pekkala S. Verbal fluency tasks and the neuropsychology of language. Faust M, editors. The Handbook of the Neuropsychology of Language. Wiley-Blackwell; 2012.p.619-634.

[7] Piatt A, Fields JA, Paolo AM, Koller WC, Tröster Al. Lexical, semantic, and action verbal fluency in Parkinson's disease with and without Dementia. J Clin Exp Neuropsychol 1999; 21(4):435-43.

[8] Baldo JV, Schwartz S, Wilkins D, Dronkers NF. Role of frontal versus temporal cortex in verbal fluency as revealed by voxelbased lesion symptom mapping. J Int Neuropsychol Soc 2006; 12(6):896-900.

[9] Libon DJ, McMillan C, Gunawardena D, et al. Neurocognitive contributions to verbal fluency deficits in frontotemporal lobar degeneration. Neurology 2009; 73(7):535-42.

[10] Beber BC, Chaves MLF. The basis and applications of action fluency and action naming tasks. Dement Neuropsychol 2014; 8(1):47-57.

[11] Piatt AL, Fields JA, Paolo AM, Tröster Al. Action verbal fluency normative data for the elderly. Brain Lang 2004; 89(3):580-3.

[12] Delbeuck X, Debachy B, Pasquier F, Moroni C. Action and noun fluency testing to distinguish between Alzheimer's disease and dementia with Lewy bodies. J Clin Exp Neuropsychol 2013; 35(3):259-68.

[13] Acevedo A, Loewenstein DA, Barker WW, et al. Category fluency test: Normative data for English - and Spanishspeaking elderly. J Int Neuropsychol Soc 2000; 6:760-769.

[14] Brucki SMD, Rocha MSG. Category fluency test: Effects of age, gender and education on total scores, clustering and switching in Brazilian Portuguese-speaking subjects. Braz J Med Biol Res 2004; 37(12):1771-7.

[15] Crowe SF. Decrease in performance on the verbal fluency test as a function of time: Evaluation in a young healthy sample. $J$ Clin Exp Neuropsychol 1998; 20(3):391-401.

[16] Sauzéon H, Raboutet C, Rodrigues J, et al. Verbal knowledge as a compensation determinant of adult age differences in verbal fluency tasks over time. J Adult Dev 2011; 18(3):144-54.

[17] Venegas MJ, Mansur LL. Verbal fluency: Effect of time on item generation. Dement \& Neuropsychol 2011; 5(2):104-7.

[18] Zimmermann N, Parente MAMP, Joanette $Y$, Fonseca RP. Unconstrained, phonemic and semantic verbal fluency: Age and education effects, norms, discrepancies. Psicol Reflex Crit 2014; 27(1):1-9.

[19] Hall JR, Harvey M, Vo HT, O'Bryant SE. Performance on a measure of category fluency in cognitively impaired elderly. Neuropsychol Dev Cogn B Aging Neuropsychol Cogn 2011; 18(3):353-61.

[20] Kim H, Kim J, Kim DY, Heo J. Differentiating between aphasic and nonaphasic stroke patients using semantic verbal fluency measures with administration time of 30 seconds. Euro Neurol 2011; 65(2):113-7.

[21] Bose A, Wood R, Kiran S. Semantic fluency in aphasia: clustering and switching in the course of 1 minute. Int J Lang Commun Disord 2017; 52(3):334-345.

[22] Carmo JC, Duarte E, Pinho S, Marques JF, Filipe CN. Verbal fluency as a function of time in autism spectrum disorder: An 
impairment of initiation processes? J Clin Exp Neuropsychol 2015; 37(7):710-721.

[23] Maviş I, Tunçer AM. Semantik Akıcılık. Detay Yayıncılık; 2013. (Turkish)

[24] Güven AG, Cangökçe Ö. The role of education levels and gender on reading and phonemic (initial letter) fluency in healthy adults. Türk Psikoloji Dergisi 2006; 21(57):121-123.

[25] Kırbaç D. 15-17 Yaş Aralığındaki Türkçe Konuşan Çocukların Fonemik, Semantik ve Eylem Akıcılığı Becerilerinin Karşılaştırılması. Anadolu Üniversitesi. Sağıık Bilimleri Enstitüsü, Yüksek Lisans Dönem Projesi, 2012. (Turkish)

[26] Yılmaz F. Türkçe Konuşan 15-17 Yaş Aralığındaki Okul Çağı Çocuklarının Sözel Akıcılık Becerilerinin Cinsiyet, Yaş, Okul Türü ve Aile Eğitim Durumu Açısından Değerlendirilmesi. Anadolu Üniversitesi. Sağlık Bilimleri Enstitüsü, Yüksek Lisans Dönem Projesi, 2012. (Turkish)
[27] Kalafatoğlu P. Alzheimer hastalığında sözel akıcılık becerilerinin incelenmesi. Anadolu Üniversitesi. Sağlık Bilimleri Enstitüsü, Yüksek Lisans Tezi, 2015. (Turkish)

[28] Karaca E. Frontotemporal lobar dejenerasyon hastalarının sözel akıcılık becerilerinin incelenmesi. Anadolu Üniversitesi. Sağlık Bilimleri Enstitüsü. Yüksek Lisans Tezi, 2015. (Turkish)

[29] Maviş I., Toğram B. Afazi Dil Değerlendirme (ADD) kullanım yönergesi. Detay Yayıncılık; 2009. (Turkish)

[30] Güngen C, Ertan T, Eker E, Yaşar R. Reliability and validity of the standardized Mini Mental State Examination in the diagnosis of mild dementia in Turkish population. Turkish Journal of Psychiatry 2002; 13(4):273-81. (Turkish)

[31] Demetriou E, Holtzer R. Mild cognitive impairments moderate the effect of time on verbal fluency performance. J Int Neuropsychol Soc 2017; 23:44-55.

How to cite this article: Ozdemir S, Tuncer AM. Verbal Fluency: An Investigation of Time Variable Among Elderly People. Clin Exp Health Sci 2021; 11: 133-139. DOI: 10.33808/clinexphealthsci.727477 